\title{
EVALUATION OF GIN WASTE AS A GROWING SUBSTRATE, ENRICHED WITH DIFFERENT VOLUME PERCENTAGE OF THE WHEAT BRAN FOR CULTIVATION OF OYSTER MUSHROOM (PLEUROTUS OSTREATUS)
}

\author{
M. M. Akhtarl, *, M. M. Jahangir², M. Zeeshan', M. Abdullah' \\ 1. World Wide Fund for Nature Pakistan (WWF-Pakistan) \\ 2. Institute of Horticultural Sciences, University of Agriculture Faisalabad, Pakistan
}

\begin{abstract}
Pleurotusostreatus mushroom was cultivated on cotton gin waste amended with wheat bran in order to judge its growth potential. Two substrates (cotton gin waste and wheat bran) were employed alone and with different combinations. Experiment consisted of four treatments T0 $(100 \%$ cotton gin waste), $\mathrm{T} 1$ ( $97 \%$ cotton gin waste $+3 \%$ wheat bran), 12 ( $94 \%$ cotton gin waste $+6 \%$ wheat bran) and $\mathrm{T} 3(91 \%$ cotton gin waste $+9 \%$ wheat bran). Data about time needed for commencement of spawn run, time needed for completion of mycelial growth, time needed for initiation of pinheads, time needed for harvesting of $1^{\text {st }}, 2^{\text {nd }}$ and $3^{\text {rd }}$ flush, fresh weight of $1 s^{t}, 2^{\text {nd }}$ and 3rd flush harvested, total yield, pH of mushroom, total soluble solids of mushroom, acidity and ascorbic acid contents, reducing sugars, non-reducing sugars and total sugars of mushroom, total nitrogen, phosphorus and potassium contents of mushroom was recorded. T0 (100\% cotton gin waste) performed better as compared to other treatments.
\end{abstract}

KEYWORDS: Cotton gin waste, wheat bran, biochemical, yield, mushroom growth

${ }^{*}$ Corresponding author: (Email: makhtar@wwf.org.pk)

\section{INTRODUCTION}

Oyster Mushroom Pleurotusostreatus is a famous mushroom and is an important part of daily diet of the people in various countries of the world like; China, Korea and Japan. This mushroom grows wildly in forests of hilly areas and flourishes better at temperature range of $22-28^{\circ} \mathrm{C}$ and atmospheric humidity more than 85\%. In Pakistan, Oyster Mushroom grows naturally on trunk of trees and stumps in Northern Areas, Azad Jamu and Kashmir [1]. Oyster Mushroom is popular enriched source of proteins, vitamins such as B, D, E, and K (fats
(0.5-3.5\%) and various health beneficial [2]. In Pakistan production of Oyster Mushroom is getting popularity due to its high economic returns. Globally farmers cultivate Oyster Mushroom on different agricultural waste materials such as wheat straw, rice straw, sorghum straw, rice husk, alang-alang grass, artichoke waste, azolla, banana leaves, banana pseudostems, bean pods, bean straw, cactus, agave and yucca, cardamon pulp, cinnamon leaves, peels of citrus fruit, coconut husks, coconut coir and coconut pith, coffee parchment, coffee sawdust corn fiber, crushed corncobs, hammer milled corn 
cob, corn stapes, corncobs, corn leaves, corn stover, corn stalks, lemon grass leaves, oat straw, ragi straw, sesame stems, sugarcane bagasse sunflower husks, sunflower peels, chopped heads and stipes of sunflower and tea leaves etc. [3].

The Cotton Gin Waste is normally composed of leaves, sticks, soil particles, burs, other plant materials, cotton lint and mote etc. One of the biggest problems faced by the cotton ginning industry in Pakistan and rest of the world is Cotton Gin Waste Management. It has been estimated that ginning one bale $(227 \mathrm{~kg}$ ) of spindle harvested seed cotton lint approximately contributes between 37 and $147 \mathrm{~kg}$ of waste [4]. As reported by the Pakistan Cotton Ginners Association (PCGA), total cotton production in Pakistan in 2012-13 stood at 12.915 million bales, approximately $12.81 \%$ or 1.898 million bales less than previous year. Considering that on the average annually about 12 million bales are ginned in Pakistan, the amount of cotton gin waste produced in Pakistan could be approximately close to 3.5 billion pounds per year.

Disposal of such huge amount of cotton gin waste is an alarming issue as it may cause serious threats to the environment. At the moment, global cotton industry is trying to reduce their cotton gin waste by alternative options for handling this as a by-product, which has potential as a multiuse product.

Use of cotton gin waste as a growing media for Oyster Mushroom cultivation could be a viable option in this regard. As growing of Oyster Mushroom on cotton gin waste can be helpful in reducing environmental pollution caused by cotton gin waste. The objective of this study was to investigate the possibility of Oyster Mushroom production on cotton waste and wheat bran and their different combinations.

\section{METHODOLOGY}

Present research work was accomplished in mushroom farm of a village in Basti Misson Bahawalpur, in a project entitled "Farmers' capacity building for mushroom growing using cotton gin waste as growing substrate" under WWF-Pakistan's SPRING project "Sustainable Cotton Production in Pakistan's Cotton Ginning SMEs" funded by European Union. While all the biochemical analysis was performed at Institute of Horticultural Sciences, University of Agriculture, Faisalabad during 2013-2014 for evaluation of growth and yield response of Oyster Mushroom specie viz. Pleurotusostreatus by using cotton gin waste mixed with wheat bran at different ratios.

Cotton waste was used as substrate in this research work. Cotton gin waste was soaked in water. Two percent lime was mixed in cotton gin waste to maintain its $\mathrm{pH}$. After soaking, the substrate was piled up and covered with polythene sheet. Cotton gin waste was allowed to ferment for 4 days. Cotton gin waste was then spread on floor for evaporation of excess water. Latter on wheat bran was added @ 3,6 and 9\% respectively. Substrate was filled in polypropylene bags of size (7×9 inch) and bags mouths were loosely tied with rubber bands. The bags were pasteurized by local method in an ordinary drum for two hours. When bags were pasteurized, they took one day for cooling. After cooling the bags were inoculated with spawn at the rate of $10 \mathrm{gm}$ per bag. During 
spawn running the temperature in growth room was controlled between $22-26^{\circ} \mathrm{C}$ for spawn running. The required humidity was maintained between $70-80 \%$ by sprinkling water on the floor several times a day.

After completion of spawn running the temperature of growing room was maintained between $16-250^{\circ} \mathrm{C}$. Fructification or fruit body was started as soon as the substrate was fully impregnated with mycelial growth. The humidity of the growing room was maintained between $80-90 \%$ by sprinkling water on floor and moisture requirements of the bags was accomplished by sprinkling water on them thrice a day using sprinkler.

Experiment was conducted under complete randomized design and every treatment was replicated five times.

$\mathrm{TO}=$ Cotton waste $(100 \%)$ control

$\mathrm{Tl}=$ Cotton waste $(97 \%)+$ Wheat bran (3\%)

$\mathrm{T} 2=$ Cotton waste $(94 \%)+$ Wheat bran $(6 \%)$

$\mathrm{T} 3=$ Cotton waste $(91 \%)+$ Wheat bran $(9 \%)$

Data regarding different parameters like time taken for commencement of spawn run (days), time taken for completion of mycelial growth (days), time taken for initiation of pinhead formation (days), Number of days for completion of 1st flush (days), Number of days for completion of 2 nd flush (days), Number of days for completion of 3rd flush (days), fresh weight of 1st flush (g), fresh weight of 2nd flush (g), fresh weight of 3rd flush (g), Total yield (g), pH, Total soluble solids ('Brix), acidity (\%) [5], Ascorbic acid (mg/100ml) [6], reducing sugars, nonreducing sugars, total sugars [5], notrogen contents of mushrooms, phosphorus contents of mushrooms and potassium contents of mushrooms [7] was commemorated.

\subsection{Statistical Analysis}

In this experiment completely randomized design (CRD) was used. The data collected sequentially was examined statistically using LSD test at $5 \%$ probability level [8].

\section{RESULTS AND DISCUSSION}

Data regarding effect of cotton gin waste, wheat bran and their different amendments on growth of Oyster Mushroom (Pleurotusostreatus) is shown in Table 1. The minimum time for commencement of spawn run was taken by TO(1.4 days) while T3 took maximum time (2.4 days) for commencement of spawn run followed by $\mathrm{T} 2$ and $\mathrm{T} 1$ respectively. Likewise, Time taken for completion of mycelial growth was commemorated in days. Treatments showed significant results regarding completion of mycelial growth. The Treatment T0 performed well and took minimum time (22 days), followed by $\mathrm{T} 1$ (30.2 days), T2 (42.4 days) and T3 (47 days) respectively for completion of mycelial growth. Time taken for initiation of pinhead formation was also commemorated in days. T0 took minimum time (26.8 days) for initiation of pinheads followed by $\mathrm{T} 1$ (34.8 days), T2(47 days)and T3(52 days) respectively as shown in Table 1. An experiment done by Khan et al. [9] support our work as they reported better performance of Pleurotus species on cotton waste as compared to different other mushroom growth media. The fluctuation in above cited parameters may be ascribed to fluctuation in lignocellulosic and chemical composition of growing substrates [10]. 
Table 1. Effect of substrate on time taken for completion of mycelia growth of Oyster Mushroom (Pleurotusostreatus).

\begin{tabular}{llcc}
\hline Treatments & $\begin{array}{l}\text { Time taken for } \\
\text { commencement } \\
\text { of spawn run } \\
\text { (days) }\end{array}$ & $\begin{array}{c}\text { Time taken } \\
\text { for } \\
\text { completion } \\
\text { of mycelial } \\
\text { growth }\end{array}$ & $\begin{array}{c}\text { Time taken for } \\
\text { initiation of } \\
\text { pin head } \\
\text { formation(da }\end{array}$ \\
\hline (days) & ys) \\
\hline T0 & $1.4000 \mathrm{C}$ & $22.000 \mathrm{D}$ & $26.800 \mathrm{D}$ \\
T2 & $1.8000 \mathrm{BC}$ & $30.200 \mathrm{C}$ & $34.800 \mathrm{C}$ \\
T3 & $2.000 \mathrm{AB}$ & $42.400 \mathrm{~B}$ & $47.000 \mathrm{~B}$ \\
LSD Value & 0.5996 & $47.000 \mathrm{~A}$ & $52.000 \mathrm{~A}$ \\
& & 2.5963 & 2.4540 \\
\hline
\end{tabular}

Figures not sharing the same letters differ significantly at $\mathrm{P}=0.05$.

Data concerning time taken for completion of 1stflush, Time taken for completion of 2 ndflush and Time taken for completion of 3rdflush is shown in Table2. T0 (31.2 days) took minimum time for completion of 1stflush followed by $\mathrm{Tl}$ (42.2 days),T2(43.2 days), and $\mathrm{T} 3(55.8$ days $)$ respectively. Likewise, T0 (39.2 days) took minimum time for completion of 2 ndflush followed by T1(49.2 days),T2(51.4 days)and T3(62.8 days) respectively. Likewise, T0 (46.8 days) took minimum time for completion of 3rdflush followed by $\mathrm{T} 1$ (56.2 days),T2(57.2 days)and T3(69.8 days) respectively. Similar behavior of mushroom harvesting pattern was reported by Dundar and Yildiz [11].
Table 2. Effect of Substrate on number of days for completion of flush of Oyster Mushroom (Pleurotusostreatus).

\begin{tabular}{llll}
\hline Treatments & $\begin{array}{l}\text { Number of } \\
\text { days for } \\
\text { completion } \\
\text { of 1st flush }\end{array}$ & $\begin{array}{l}\text { Number of } \\
\text { days for } \\
\text { completion of }\end{array}$ & $\begin{array}{l}\text { 2nd flush } \\
\text { days for } \\
\text { completion of } \\
\text { 3rd flush }\end{array}$ \\
\hline T0 & $31.200 \mathrm{C}$ & 39.200 C & $46.800 \mathrm{C}$ \\
T1 & $42.200 \mathrm{~B}$ & $49.200 \mathrm{~B}$ & $56.200 \mathrm{~B}$ \\
T2 & $43.200 \mathrm{~B}$ & $51.400 \mathrm{~B}$ & $57.200 \mathrm{~B}$ \\
T3 & $55.800 \mathrm{~A}$ & $62.800 \mathrm{~A}$ & $69.800 \mathrm{~A}$ \\
LSD Value & 3.8974 & 3.8743 & 4.0667 \\
\hline
\end{tabular}

Figures not sharing the same letters differ significantly at $P=0.05$.

Data regarding Fresh weight of 1stflush (g), Fresh weight of 2ndflush (g), Fresh weight of 3rdflush (g) and Total yield ( $g$ ) is shown in Table 3. In case of fresh weight of 1stflush harvested T0 yielded best (76.2 g) followed by $\mathrm{T} 1(63.4 \mathrm{~g}), \mathrm{T} 2(50 \mathrm{~g})$ andT3 $(42.2 \mathrm{~g})$ respectively. While, in case of fresh weight of 2 ndflush harvested T0 yielded best ( $48.6 \mathrm{~g}$ ) followed by $\mathrm{T} 1(39.75 \mathrm{~g}), \mathrm{T} 2(31.20 \mathrm{~g})$ and $\mathrm{T} 3(22.8 \mathrm{~g})$ respectively. Similarly, in case of fresh weight of 3rdflush harvested T0 yielded best (35.99 g) followed by $\mathrm{Tl}(28.31 \mathrm{~g}), \mathrm{T} 2(20.95 \mathrm{~g})$ and T3(15.76 g) respectively. On the other hand, in case of total yield T0 performed best (159.8 g) followed by T1(131.39 g),T2(107.86 g)and T3(80.76 g) respectively. With the passage of time gradual decrease in mushroom yield was noticed from 1st flush to 3rd flush which might be ascribed to gradual reduction in nitrogen contents of substrates [12]. 
Table 3. Effect of substrate on yield parameters of Oyster Mushroom (Pleurotusostreatus).

\begin{tabular}{|c|c|c|c|c|}
\hline Treatments & $\begin{array}{l}\text { Fresh weight } \\
\text { of } 1 \text { st flush } \\
\text { (g) }\end{array}$ & $\begin{array}{l}\text { Fresh } \\
\text { weight of } \\
\text { 2nd } \\
\text { flush(g) }\end{array}$ & $\begin{array}{l}\text { Fresh } \\
\text { weight of } \\
\text { 3rd } \\
\text { flush(g) }\end{array}$ & $\begin{array}{l}\text { Total } \\
\text { yield (g) }\end{array}$ \\
\hline TO & $76.200 \mathrm{~A}$ & $48.600 \mathrm{~A}$ & $35.998 \mathrm{~A}$ & $159.80 \mathrm{~A}$ \\
\hline $\mathrm{Tl}$ & $63.400 \mathrm{~A}$ & $39.756 \mathrm{AB}$ & $28.31 \mathrm{~B}$ & $131.39 \mathrm{~B}$ \\
\hline $\mathrm{T} 2$ & $50.000 \mathrm{~B}$ & $31.204 \mathrm{BC}$ & $20.952 \mathrm{C}$ & $107.86 \mathrm{C}$ \\
\hline T3 & $42.200 \mathrm{~B}$ & $22.800 \mathrm{C}$ & $15.76 \mathrm{D}$ & $80.76 \mathrm{D}$ \\
\hline LSD Value & 13.046 & 10.975 & 4.0811 & 16.991 \\
\hline
\end{tabular}

Figures not sharing the same letters differ significantly at $P=0.05$.

Data regarding $\mathrm{pH}$, Total soluble solids (OBrix), Acidity of mushroom (\%) and Ascorbic acid contents of mushroom (mg/100ml) is shown in Table 4. Highest $\mathrm{pH}$ value was observed in case of T3 (7.96) followed by T2(7.84),T1 (7.7)and TO(7.54) respectively. In case of total soluble solids of mushroom maximum total soluble solids were observed in case of TO (3.6) followed byT1 (3.3) and T2 (3.19) and T3(3.02) respectively. In case of acidity of mushroom Maximum acidity of mushroom was observed in case of T0 (0.042) followed by $\mathrm{T} 1$ (0.036), T2(0.034) and T3(0.032) respectively. In case of ascorbic acid contents of mushroom, maximum ascorbic acid contents were observed in case of TO $(10.61 \mathrm{mg} / 100 \mathrm{ml})$ followed by $\mathrm{T} 1(8.2$ $\mathrm{mg} / 100 \mathrm{ml})$, T2 $(7.4 \mathrm{mg} / 100 \mathrm{ml})$ and T3 $(7.0$ $\mathrm{mg} / 100 \mathrm{ml}$ ) respectively. Mycelial growth is maximum at high $\mathrm{pH}$ while it is minimum at low $\mathrm{pH}$ [13].
Table 4. pH of substrate their amendments on biochemical attributes of Oyster Mushroom (Pleurotusostreatus).

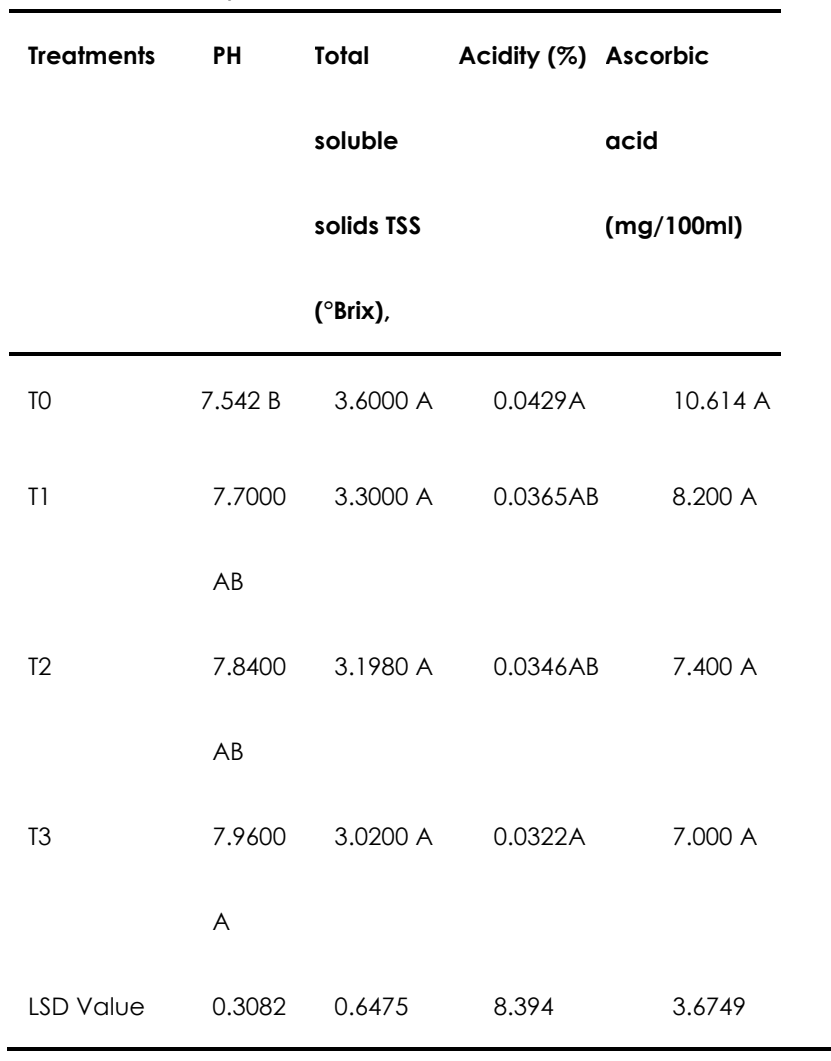

Figures not sharing the same letters differ significantly at $P=0.05$.

Data regarding reducing sugars contents of mushroom (\%), non-reducing sugars of mushroom (\%) and total sugar contents of mushroom (\%) is shown in Table 5. In case of reducing sugars contents of mushroom (\%), maximum reducing sugars contents were observed in case of TO $(3.44 \%)$ followed by $\mathrm{T} 1(3.35 \%), \quad \mathrm{T} 2(3.21 \%)$ and $\mathrm{T} 3(3.15 \%)$ respectively. Similarly, in case of non-reducing sugars contents of mushroom (\%), maximum non reducing sugars contents were observed in case of TO $(6.99 \%)$ followed by $\mathrm{Tl}(6.18 \%)$, $\mathrm{T} 2(6.03 \%)$ and $\mathrm{T} 3(5.96 \%)$ respectively. similarly, in case of total sugars contents of mushroom (\%), maximum total sugars contents were observed in case of $\mathrm{Tl}(10.51 \%)$ followed by TO(10.49\%), T2(9.97\%) and T3(9.34\%) 
respectively. Maximum Non reducing sugars, reducing sugars in mushroom were observed which grow on substrate having cotton wastes only [13].

Table 5. Effect of substrate and their amendments on reducing sugars, non-reducing sugars and total sugars of Oyster Mushroom (Pleurotusostreatus).

\begin{tabular}{llll}
\hline Treatments & Reducing & Non reducing sugars & Total \\
& sugars(\%) & $(\%)$ & sugars (\%) \\
& & & \\
\hline T0 & $3.4440 \mathrm{~A}$ & $6.9980 \mathrm{~A}$ & $10.492 \quad \mathrm{~A}$ \\
T1 & $3.3580 \mathrm{AB}$ & $6.1840 \mathrm{~B}$ & $10.518 \quad \mathrm{~A}$ \\
T2 & $3.2180 \mathrm{AB}$ & $6.0340 \mathrm{~B}$ & $9.9780 \mathrm{AB}$ \\
T3 & $3.1520 \mathrm{~B}$ & $5.9680 \mathrm{~B}$ & $9.3460 \quad \mathrm{~B}$ \\
LSD Value & 0.2298 & 0.6131 & 0.8380
\end{tabular}

Figures not sharing the same letters differ significantly at $P=0.05$.

Data about nitrogen contents of mushroom (\%), phosphorus contents of mushroom (\%) and potassium contents of mushroom (\%) is shown in Table 6. In case of nitrogen contents of mushroom (\%), maximum nitrogen contents were observed in case of T0 (0.71\%) followed by $\mathrm{T} 1(0.69 \%), \mathrm{T} 2(0.60 \%)$ and $\mathrm{T} 3(0.50 \%)$ respectively. Similarly, in case of phosphorus contents of mushroom (\%), maximum phosphorus contents were observed in case of T0 $(0.45 \%)$ followed by $\mathrm{T} 1(0.43 \%), \quad \mathrm{T} 2(0.31 \%)$ and $\mathrm{T} 3(0.24 \%)$ respectively. Likewise, in case of potassium contents of mushroom maximum potassium contents were observed in case of T0 $(0.76 \%)$ followed by $\mathrm{T} 1(0.70 \%), \mathrm{T} 2$ (0.57 \%) and
$\mathrm{T} 3(0.56 \%)$ respectively. It is reported that Phosphorus, potassium and sodium are vital minerals of mushrooms [14].

Table 6. Effect of substrate and their amendments on Nitrogen, Phosphorus and Potassium contents of Oyster Mushroom (Pleurotusostreatus).

\begin{tabular}{llll}
\hline Treatments & Mushroom & Mushroom & Mushroom \\
& Nitrogen & Phosphorus & Potassium \\
& contents (\%) & contents (\%) & contents \\
& & & (\%) \\
\hline T0 & $0.7140 \mathrm{~A}$ & $0.4540 \mathrm{~A}$ & $0.7660 \mathrm{~A}$ \\
T1 & $0.6900 \mathrm{~A}$ & $0.4360 \mathrm{~A}$ & $0.7080 \mathrm{~A}$ \\
T2 & $0.6000 \mathrm{~B}$ & $0.3140 \mathrm{~B}$ & $0.5780 \mathrm{~B}$ \\
& & & $0.5600 \mathrm{~B}$ \\
T3 & $0.5000 \mathrm{C}$ & $0.2460 \mathrm{C}$ & 0.1076 \\
\hline
\end{tabular}

Figures not sharing the same letters differ significantly at $P=0.05$.

\section{CONCLUSION}

It can be concluded from the present research that T0, which is $100 \%$ cotton gin waste used as growing substrate, performed best as compared to other Treatment. So, cotton gin waste can be successfully used for cultivation of high quality Oyster Mushroom (Pleurotusostreatus).

\section{References}

[1] Z. Sher, F. Hussain and L. Badshah. Micromineral contents in eight forage shrubs at three phenologicaltages in a Pakistan's rangeland. African Journal of Plant Science, 5 (2011) 557564

[2] M. Bozena, S. Katarzyna, L. Mciej, O. Wlodzenriers, Z. Magdalena, R. Jack. Edible 
Mushrooms in Prophylaxis and Treatment of Human Diseases. J. MIR. 4 (2013)170-183

[3] M. S. Sangwan and L. C. Saini. Cultivation of Pleurotussajorcaju (Fr.) Singer on agro-industrial wastes. Mushroom Res. 4 (1995) 33-34.

[4] J. A. Thomasson, A Review of Cotton Gin Trash Disposal and Utilization. Beltwide Cotton Conferences: (1990)689-705.

[5] W. Hortwitz, Official and Tentative Methods of Analysis, 9(1960) 320-41. Association of the Official Agriculture Chemist. Washington, D.C.

[6] J. A. Ruck, Chemical Methods for Analysis of Fruits and Vegetables. Research Station Summerland, Canada Department of Agriculture, (1969) Publication No:1 154

[7] D. H. Chapman and F. Parker, Determination of NPK. In: Methods of analysis for soils, plants and water. 1st Ed. California University, Agriculture Division, USA. (1961) 150-179.

[8] R.G.D. Steel, J. H. Torrie and D.A. Dickey. 1997. Principles and Procedures of Statistics: A Biometrical Approach. 3rd ed. McGraw Hill Book Co., New York.

[9] N. A. Khan, M. I. Haq and M. A. Khan. Growth comparison of local and exotic strains of oyster mushrooms on different agricultural wastes. Pak. J. Phytopathol. 21 (2009) 139-143.

[10] E. A. Adebay and D. Martinez- Carrera. Oyster Mushrooms (pleurotus)are useful for utilizing lignocellulosic biomass. African Journal of Biotechnology, 14 (2015) 52-67

[11] A. Dundar and A. Yildiz. A comparative study on Pleurotusostreatus (jacq.) P. kumm. cultivated on different agricultural lignocellulosic wastes. Turk. J. Biol., 33 (2009) 171-179.
[12] M. M. Jahangir, G. Samin, N. A. Khan, A. Rehman, Z. Aslam, M. Amjad, K. Ziaf, R.W.K. Qadri, I. Khan and M. Atiq. Performance of Oyster Mushroom (Pleurotus) grown on cotton waste and sorghum straw based growing substrate. Pak. J. Phytopathol. 27 (2015) 77-81.

[13] H. Sardar, M. A. Ali, C. M. Ayyub, and R. Ahmad. Effect of different culture media, temperature and $\mathrm{pH}$ level on the growth of wild and exotic pleurotus species. Pak. J. Phytophathol. 25 (2015) 139-145. 